ISSN 0258-7122

Bangladesh J. Agril. Res. 38(4): 673-688, December 2013

\title{
EFFECT OF PLANTING TIME AND NITROGEN APPLICATION ON THE YIELD AND SEED QUALITY OF T. AMAN RICE (Oryza sativa L.)
}

\author{
A. S. M. I. HUSSAIN ${ }^{1}$, M. M. HOQUE 2 , M. N. $\operatorname{HUDA}^{3}$ \\ D. HOSSAIN ${ }^{4}$ AND M. SHAHJAHAN ${ }^{5}$
}

\begin{abstract}
A field experiment was conducted at the research farm of Bangabandhu Sheikh Mujibur Rahman Agricultural University, Gazipur during June 2006 to December 2007 to find out the effect of planting time and nitrogen fertilization on the yield and seed quality of T.Aman rice. BR11 ( Mukta) was transplanted at different dates from 5 July to 19 August at 15 days interval. The rates of $\mathrm{N}$ used in the experiment were $80,100,120$, and $140 \mathrm{~kg} \mathrm{~N} / \mathrm{ha}$, Plant height, number of tillers/hill, grain yield, and yield components parameters varied significantly due to transplanting of rice at variable dates. The optimum time of planting was found to be 4 August compared to other dates of transplanting. Result indicates that this variety planted in optimum time gave higher yield with high quality of rice seed. In comparison to early and late planting, earlier planting of the variety was better as the late planted crops were severely affected by adverse environmental condition during reproductive phase. The poor grain yield in early or late planting was due to higher percentage of spikelet sterility. The varieties responded positively with increment of $\mathrm{N}$ levels upto $120 \mathrm{~kg} \mathrm{~N} / \mathrm{ha}$. The higher number of panicles $/ \mathrm{m}^{2}$, lower percentage of unfilled grain, and heavier individual grain contributed to increase grain yield of this verity. It is, therefore, suggested to transplant BR11 rice in the first week of August in Aman season. The application of $\mathrm{N}$ of $100-120 \mathrm{~kg} / \mathrm{ha}$ with three splits is optimum for achieving higher grain yield and better quality of rice seed.
\end{abstract}

Keywords: BR11, planting time, nitrogen, yield, seed quality.

\section{Introduction}

Rice (Oryza sativa) is predominant in Bangladesh agriculture covering about 9 million hectares of total arable land. It constitutes about $93 \%$ of the total cereal production and alone accounts for $20 \%$ of the gross domestic product of the country. It contributes $76 \%$ of daily calories and $66 \%$ of protein intake to general people of Bangladesh (Dey et al., 1996). Despite such importance of rice in Bangladesh, the average rice yield is only $1.94 \mathrm{t} / \mathrm{ha}$ (BBS, 2009), which is very low compared to other advanced rice growing countries like South Korea, Spain,

${ }^{1}$ Professor, Dept. of Agronomy, Patuakhali Science \& Technology University (PSTU), Patuakhali, ${ }^{2}$ Professor, Dept. of Agronomy, Bangabandhu Sheikh Mujibur Rahman Agricultural University (BSMRAU), Gazipur, ${ }^{3}$ Seed Specialist, Bangladesh Agricultural Development Corporation (BADC), ${ }^{4}$ Professor, Dept. of Soil Science, PSTU, Patuakhali, ${ }^{5}$ Chief Scientific Officer, Forestry Unit, Bangladesh Agricultural Research Council (BARC), Farmgate, Dhaka, Bangladesh. 
Australia, China, and Japan where the average yield is more than $5 \mathrm{t} / \mathrm{ha}$ (FAO, 1998). Therefore, it is urgently needed to increase rice yield in order to meet the growing food demand of Bangladesh.

Planting time affects not only growth and productivity of Aman rice but also affects generously on seed quality. Planting time affects seed quality through affecting seed growth and development as it prevail different environmental conditions in the processes of seed development and seed maturation (Castillo et al., 1994). Seed quality differs even in early, mid and late maturing crops. Sing and Gill (1981) reported that early maturing crops produce poor quality seed because these remain longer time in the field during warm weather although the reverse is true in many other crops.

The potential for increasing rice production strongly depends on the ability to integrate a better crop management for the different varieties into existing cultivation systems (Mikkelsen et al., 1995). A higher output per unit area also demands considerable amounts of external inputs, such as fertilizers. Nitrogen is the most essential clement in determining the yield potential of rice and nitrogenous fertilizers are one of the major inputs to quality seed production of rice (Mae, 1997). Both over fertilization and inadequate supply of nitrogen may decrease grain yield and seed quality of rice (Henan and Bacon, 1987). The degree of seed setting and grain development of T. Aman rice under different planting times and nitrogen application is variable under the condition of soil, season, and the variety use and for T.Aman rice cultivation and the objective was to determine optimum planting time and nitrogen requirement for higher yield and quality seed production and to identify the proper mode of nitrogen application for better seed quality of T. Aman rice variety (var. BR11).

\section{Materials and Method}

A field experiment was conducted at the experimental farm of Bangabandhu Sheikh Mujibur Rahman Agricultural University, Gazipur under wetland condition during the rainy season of 2006. The location of the experimental site was $24.09^{0} \mathrm{~N}$ latitude and $90.26^{\circ} \mathrm{E}$ longitude with an elevation of $8.2 \mathrm{~m}$ from sea level. The soil of the experimental field belongs to the Shallow Red-Brown Terrace type under Salna series (Haider et al., 1991) of Madhupur Tract (AEZ 28).

The weather of the experimental site was sub-tropical in nature having rainfall in the mid June to mid September with gradual fall in temperature from last week of October. The maximum and minimum temperature was 27.01 and $33.52^{0} \mathrm{C}$, respectively.

There were three sets of treatments in the experiment. First set was planting time of rice viz., 5 July, 20 July, 4 August and 19 August, second set was nitrogen levels viz., 80-100-120-140 kg N/ha and third set was mode of nitrogen 
application viz., three splits and four splits as top dressing. The design of the experiment was split-split plot where planting times where assigned on main plot, nitrogen on subplot, and mode of nitrogen application on sub-sub plot. Treatments were replicated three times. Unit plot size was $4 \mathrm{~m} \times 3 \mathrm{~m}$. Unit plot and block was separated for irrigation and drainage by $0.5 \mathrm{~m}$ and $1.0 \mathrm{~m}$, respectively.

The soil was silty clay loam having bulk density $1.21 \mathrm{~g} / \mathrm{cc}$, particle density $2.28 \mathrm{~g} / \mathrm{cc}$, soil porosity $47.50 \%$, $\mathrm{pH} 5.80$, organic carbon $0.68 \%$, total nitrogen $0.07 \%$, available P $16.90 \mathrm{mg} / \mathrm{kg}$ soil, exchangeable K $0.55 \mathrm{meq} / 100 \mathrm{~g}$ soil, available S $2.78 \mathrm{mg} / \mathrm{kg}$ soil and available B $0.19 \mathrm{mg} / \mathrm{kg}$ soil.

Thirty five days old rice (var. BR11) seedlings were transplanted on specific dates (treatment wise) using one seedling per hill at a spacing of $20 \mathrm{~cm} \times 20 \mathrm{~cm}$. The crop was fertilized with four levels of nitrogen as per treatments and $\mathrm{P}, \mathrm{K}, \mathrm{S}$, and Zn were applied as par recommendation for rice (BRRI, 2004). All fertilizers except urea were applied as basal before the last harrowing during final land preparation. In mode of nitrogen application with three splits, urea was top dressed in three equal splits at 7 days after transplanting (DAT), maximum tillering stage, and the panicle initiation (PI) stage. While in mode of nitrogen application with four splits urea was top dressed at 7 (DAT), maximum tillering stage, the panicle initiation (PI) stage, and 7 days after flowering.

In order to keep the crop weed free the land was weeded manually. The first weeding was done at 15 and second at 30 DAT. Due to the shortage of rain water, irrigation was applied during land preparation, transplanting, and at different crop growth stages to avoid water stress. During crop growth, the field was irrigated to maintain a thin layer $(2-3 \mathrm{~cm})$ of water although at maturity no standing water was allowed to stay in the crop field. Insecticides were applied time to time to control insect pest.

Crop was harvested at proper maturity with sickle. Harvesting was done at different dates due to the variation of planting dates. An area of $6 \mathrm{~m}^{2}$ was harvested from the centre of each plot to estimate the grain yield. The harvested samples were threshed using paddle thresher, cleaned the grains, and dried to adjust at $14 \%$ moisture content.

For yield attributes, plant height was recorded from 10 randomly selected plants from each plot. The height was recorded from base of the plant to tip of upper most spikelet of the panicle. Total number of hills from $1 \mathrm{~m}^{2}$ area was harvested and the numbers of panicles were counted. Twenty panicles were randomly taken from the sample and panicle length was measured from the neck to the top of the panicle. After counting the panicle number, all spikelets from the panicles were placed in a paper bag that has been properly labeled. The total grains were counted including filled and sterile spikelet. Thousand of grains 
were randomly selected and dried to $14 \%$ moisture content and then weighed in an electrical balance. The harvested seeds of each transplanting time were stored in plastic airtight container for determination of seed quality parameters.

Quality of fresh seed harvested rice seed were assessed by germination test, speed of germination, seedling vigour, seedling length, seedling dry weight, electrical conductivity test, and soluble protein content as per following procedures.

One hundred seeds harvested from different $\mathrm{N}$ levels of each planting time were used and replicated four times. Seeds were placed in petridish containing filter paper soaked with distilled water. Then the petridishes were placed in an incubator at $30^{\circ} \mathrm{C}$ till the completion of germination. Seedlings were counted every day and a seed was considered to be germinated as seed coat ruptured and radical came out up to $2 \mathrm{~mm}$ in length. Final germination count was made according ISTA (2006).

Germination percentage was calculated by using the following formula:

Germination $(\%)=\frac{\text { Number of seeds germinated }}{\text { Number of seeds tested }} \times 100$

The speed of germination of seed sample was monitored by counting the germinated seedling at an interval of 24 hours and continued for twelve days. Co-efficient of germination and vigour index were calculated using the following formula (Copeland, 1976):

Co-efficient of germination $=\frac{100(\mathrm{~A} 1+\mathrm{A} 2+\cdots+-+\mathrm{Ax})}{\mathrm{A} 1 \mathrm{~T} 1+\mathrm{A} 2 \mathrm{~T} 2+\cdots-\cdots+\mathrm{AxTx}}$

Where,

$$
\begin{aligned}
& \mathrm{A}=\text { number of seeds germinated } \\
& \mathrm{T}=\text { Time corresponding to } \mathrm{A} \\
& \mathrm{x}=\text { number of days to final count }
\end{aligned}
$$

Seedling vigour was calculated from a daily count of germinated seeds until it reached a constant value following the formula given by Maguire (1962).

$\mathrm{SV}=\frac{\text { Number of normal seedlings (first count) }}{\text { Days to first count }}+--+$

Number of normal seedlings (last count)

Days to last count 
Seedling obtained from standard germination test was used for seedling evaluation. Normal or abnormal seedlings are classified according to the rules of International Seed Testing Association (ISTA, 2006). Seedling shoot and root length was also measured at the end of the germination test. Ten seedlings from each petridish were harvested and shoot and root length of individual seedlings was measured. The shoot and root were also dried at $70^{\circ} \mathrm{C}$ for 72 hours for determination of seedling dry matter yield.

For electrical conductivity test, 50 seeds were weighed and soaked in $50 \mathrm{ml}$ of de-ionized water for 24 hours at $25 \pm 1^{0} \mathrm{C}$ (Ali et al., 2005). After 24 hours, water of the beaker containing seeds was decanted in order to separate the seeds. The leachates conductivity was determined in $\mu \mathrm{sm}^{-1}$ by using a conductivity meter (Model-CM-30ET). Four replicates of measurements were made for each sample of seeds.

Nitrogen content in the seeds was determined following micro Kjeldahl digestion colorimetric method (Cataldo et al., 1974) at final harvest and protein content was calculated by multiplying the nitrogen content (\%) in seeds by a factor of 5.95 (Juliano, 1972).

All data were subjected to statistical analysis by analysis of variance (ANOVA). Microsoft EXCEL and MSTAT software programmes were used wherever appropriate to perform statistical analysis. Functional relationships among the parameters were established through correlation analysis.

\section{Results and Discussion}

\section{Plant height}

Transplanting times significantly influenced on plant height of Aman rice (Fig. 2). Plant height decreased as the planting time delayed. The tallest plant (127.98 $\mathrm{cm}$ ) was produced when transplanting was done at the earliest date on 5 July. The shortest plants $(115.35 \mathrm{~cm})$ were found from 19 August. Earlier planted crop received high rainfall and high temperature (Fig. 2) which favoured better growth and enhanced the plant height (Rahman, 2003).

Applied nitrogen also increased the plant height of Aman rice (Fig. 1). The tallest plant $(127.76 \mathrm{~cm})$ was found with $140 \mathrm{~kg} \mathrm{~N} / \mathrm{ha}$ and the shortest (122.79 $\mathrm{cm})$ with $80 \mathrm{~kg} \mathrm{~N} / \mathrm{ha}$. Nitrogen influenced cell division and cell elongation and ultimately increases plant height (Mannan, 2005). Mode of nitrogen application, however, did not significantly increased height of the variety. 


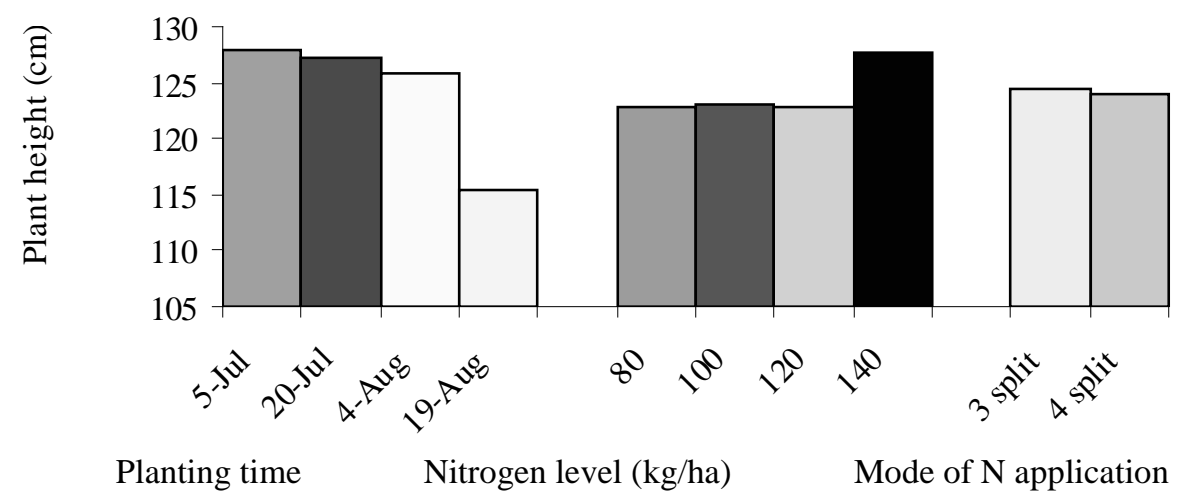

Fig. 1. Effect of different planting time, nitrogen level and mode of $\mathrm{N}$ application on plant height of Aman rice (var. BR 11).

\section{Tillers per hill}

Date of transplanting also exerted significant influence on number of tillers per hill (Fig. 1). The results revealed that the number of tillers per hill decreased gradually with the advent in planting time. The highest number (11.31) of tillers per hill was observed at 5 July transplanting rice seedling and the lowest (9.67) was recorded from the late planted rice (19 August). The number of tillers per hill decreased in delayed planting as it got lesser time for tiller development (Schnier et al., 1990).

Number of tillers increased significantly with the increase of nitrogen level. The application of nitrogen promoted the development of tillers. The highest number of tillers per hill (11.00) was produced when the crop was fertilized with $140 \mathrm{~kg} \mathrm{~N} / \mathrm{ha}$ and the lowest (10.10) was obtained from $80 \mathrm{~kg}$ N/ha treated crop. The results are in full compliance with those of Maske et al. (1997) who reported increased number of tillers per hill with increased nitrogen level. Tillers number per hill was identical in different split of nitrogen application.

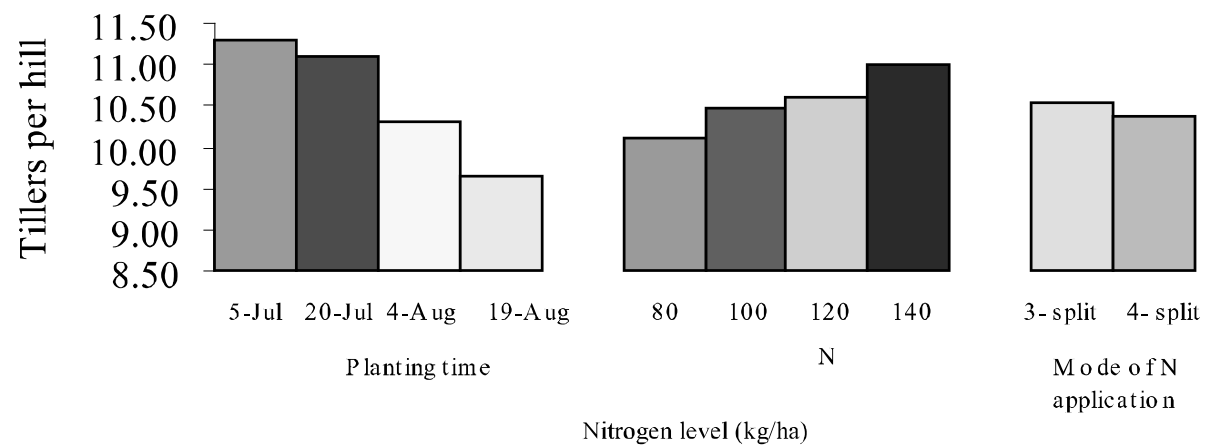

Fig. 2. Tillers per hill of Aman rice (var. BR11) as affected by planting time, nitrogen level and mode of nitrogen application. 


\section{Panicles per hill}

Grain yield can be described as the product of the number of panicles per unit area, the number of spikelets/panicle, percentage of filled spikelets, and the mean kernel weight. Each of these components has its own critical period, which is largely influenced by prevailing environment of the crop growing season. Among the yield components, number of panicles is very important for final yield of rice. The results presented in (Fig. 2) indicated that planting times significantly affected the number of panicles/hill. The highest number of panicles per hill (10.11) produced on 4 August transplanted rice and the lowest (7.93) was on 19 August planted rice. It is observed that the number of panicles per hill gradually increased till 4 August planting and it decreased beyond that date. Singh et al. (2002) also observed similar response in number of panicles/hill in late planting rice.

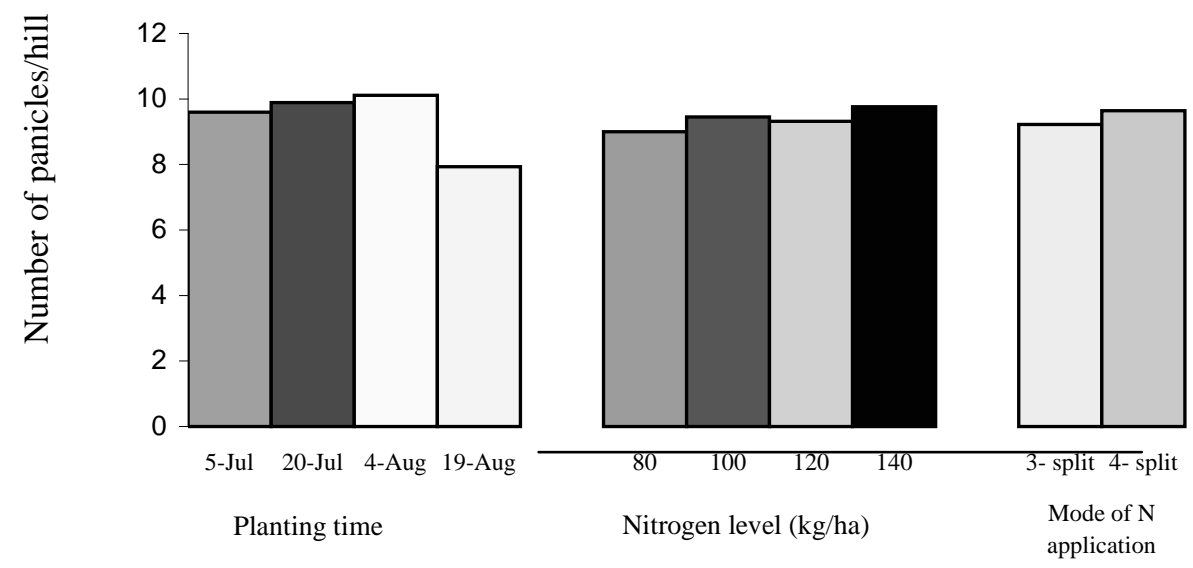

Fig. 3. Number of panicles per hill of Aman rice (var.BR11) as affected by planting time, nitrogen level and mode of $\mathrm{N}$ application.

Number of panicles/hill varied significantly due to different levels of nitrogen application. The number of panicles/hill increased with the increase of $\mathrm{N}$ rates upto $140 \mathrm{~kg} \mathrm{~N} / \mathrm{ha}$ (Fig. 3). The highest number of panicles/hill (9.76) was produced when the crop was fertilized with $140 \mathrm{~kg} \mathrm{~N} / \mathrm{ha}$ and the lowest (9.00) was obtained from $80 \mathrm{~kg} \mathrm{~N} / \mathrm{ha}$. Adequate supply of nitrogen probably favoured the cellular activities during panicle formation which led to increased number of panicles per hill (Khush 1996). Number of panicles/hill did not vary significantly due to variation of mode of nitrogen application.

\section{Grains per panicle}

The number of grains per panicle varied with the variation of dates of planting of the variety (Table 1). Crops planted in August 4 produced the highest number of grains/panicle (131.42) and the lowest number of grains/panicle 
(117.04) was found from rice planted in 5 July. Better growth of the variety of 4 August transplanting might increase panicle length which beared the highest number of grains per panicle.

The number of grains/panicle also varied significantly due to applied nitrogen. The number of grains/panicle (130.63) increased with the increase of nitrogen up to $120 \mathrm{~kg} \mathrm{~N} / \mathrm{ha}$ which was identical to $140 \mathrm{~kg} \mathrm{~N} / \mathrm{ha}$. It might be due to the application of higher doses of nitrogen which produced more biomass and translocated to grain development. Mode of $\mathrm{N}$ application, however, showed insignificant effect on grains per panicle.

\section{Unfilled grains per panicle}

Number of unfilled grains/panicle differed significantly due to different dates of transplanting of aman rice. The highest number (34.91) of unfilled spikelets/panicle was recorded on 19 August transplanting and the lowest (16.56) was observed in 4 August transplanting (Table 1). The highest number of unfilled grains/panicle in the late planted crop was the resultant of adverse effect of low temperature which might have caused spikelet sterility. Generally, rice flowers open about 10 to 12 hours and the minimum temperature of $22^{\circ} \mathrm{C}$ may be experienced during anthesis (Yoshida, 1981). Such, low temperature causes delaying of flowering, failure to produce anthers, poor filling of grain and higher grain sterility. Further, crop planted on 19 August lodged due to strong wind at grain filling stage which enhanced sterility of the variety.

Table 1. Effect of planting time, nitrogen level and mode of $\mathbf{N}$ application on yield contributing character of Aman rice (var. BR11).

\begin{tabular}{lcccc}
\hline \multicolumn{1}{c|}{ Management } & Grains/panicle & $\begin{array}{c}\text { Unfilled grains/ } \\
\text { panicle }\end{array}$ & $\begin{array}{c}\text { Filled grains/ } \\
\text { panicle }\end{array}$ & $\begin{array}{c}1000 \text {-seed } \\
\text { wt (g) }\end{array}$ \\
\hline Planting time & & & & \\
5 July & $117.04 \mathrm{c}$ & $21.45 \mathrm{~b}$ & $95.59 \mathrm{bc}$ & $23.11 \mathrm{a}$ \\
20 July & $127.61 \mathrm{~b}$ & $22.51 \mathrm{~b}$ & $104.91 \mathrm{~b}$ & $23.15 \mathrm{a}$ \\
4 August & $131.42 \mathrm{a}$ & $18.56 \mathrm{c}$ & $113.05 \mathrm{a}$ & $24.83 \mathrm{a}$ \\
19 August & $120.93 \mathrm{~b}$ & $30.91 \mathrm{a}$ & $90.02 \mathrm{c}$ & $22.51 \mathrm{~b}$ \\
Nitrogen level (kg/ha) & & & & \\
80 & $117.61 \mathrm{c}$ & $24.63 \mathrm{~b}$ & $92.98 \mathrm{c}$ & $22.82 \mathrm{~b}$ \\
100 & $126.48 \mathrm{~b}$ & $24.02 \mathrm{~b}$ & $102.46 \mathrm{~b}$ & $23.04 \mathrm{a}$ \\
120 & $130.63 \mathrm{a}$ & $21.48 \mathrm{c}$ & $109.15 \mathrm{a}$ & $23.56 \mathrm{a}$ \\
140 & $130.27 \mathrm{a}$ & $27.30 \mathrm{a}$ & $102.97 \mathrm{~b}$ & $23.19 \mathrm{a}$ \\
Mode of N application & & & & \\
3 split & $126.07 \mathrm{a}$ & $103.41 \mathrm{a}$ & $22.66 \mathrm{~b}$ & $22.92 \mathrm{~b}$ \\
4 split & $126.43 \mathrm{a}$ & $100.38 \mathrm{~b}$ & $26.05 \mathrm{a}$ & $23.39 \mathrm{a}$ \\
\hline
\end{tabular}

Means in a column followed by same letter (s) are not significantly different at $5 \%$ level of significance by DMRT 
A significant difference in number of unfilled grains/panicle was found due to different levels of nitrogen. The maximum number of unfilled grains/panicle (27.30) was recorded from $140 \mathrm{~kg} \mathrm{~N} / \mathrm{ha}$ and the lowest was observed (21.48) from $80 \mathrm{~kg} \mathrm{~N} / \mathrm{ha}$. The highest number of unfilled grains/panicle at $140 \mathrm{~kg} \mathrm{~N} / \mathrm{ha}$ indicates that this level of nitrogen was probably a case of over dose of nitrogen. The highest dose of nitrogen application increased tallness of plant that enhanced lodging during grain filling stage resulting in higher spikelet sterility. In this context, increase in split application of nitrogen reduced the sterility of rice. Four split application of nitrogen reduced (29.11\%) sterility over the three split.

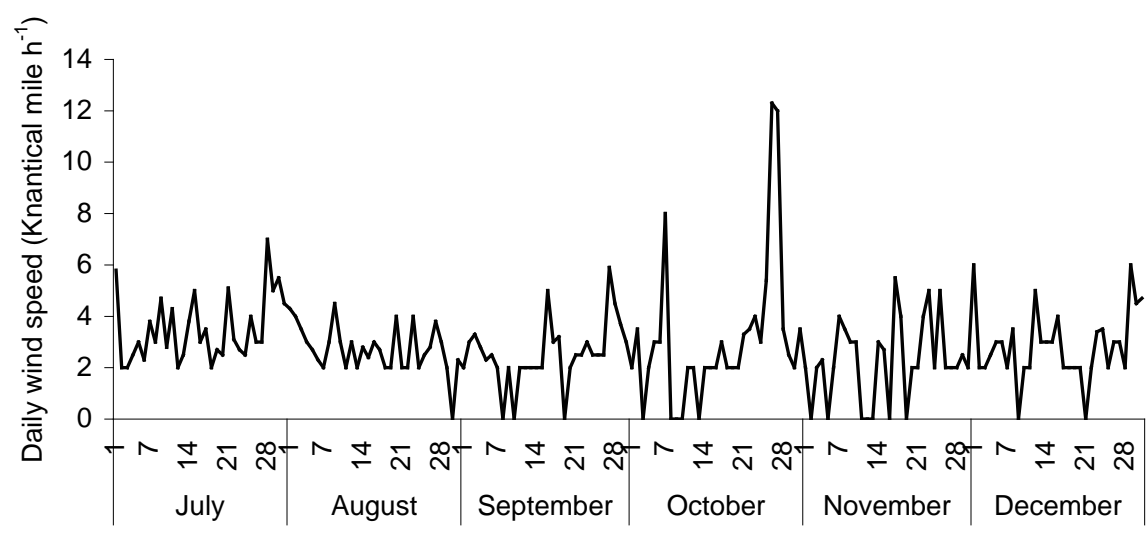

Fig. 4. Daily wind speed prevails during whole Aman rice (var. BR11) growing season.

\section{Filled grains per panicle}

Number of filled grains/panicle was significantly influenced by date of transplanting. The highest number of grains/panicle (111.05) was observed in 4 August transplanting of rice. After that it decreased drastically and the lowest number of grains/panicle was found (94.02) on 19 August transplanting rice (Table 1). Such variability in filled spikelets/panicle is expected as number of filled spikelets/panicle is dependent on many factors, such as genotypes, cultural techniques used, soil and growing environment of the crop (Baloch et al., 2006). In present study, cultural technique like different planting times allowed the crop to complete its life cycle under a wide range of environmental conditions which might have influenced on number of filled spikelet/panicle of the variety over the planting times. 


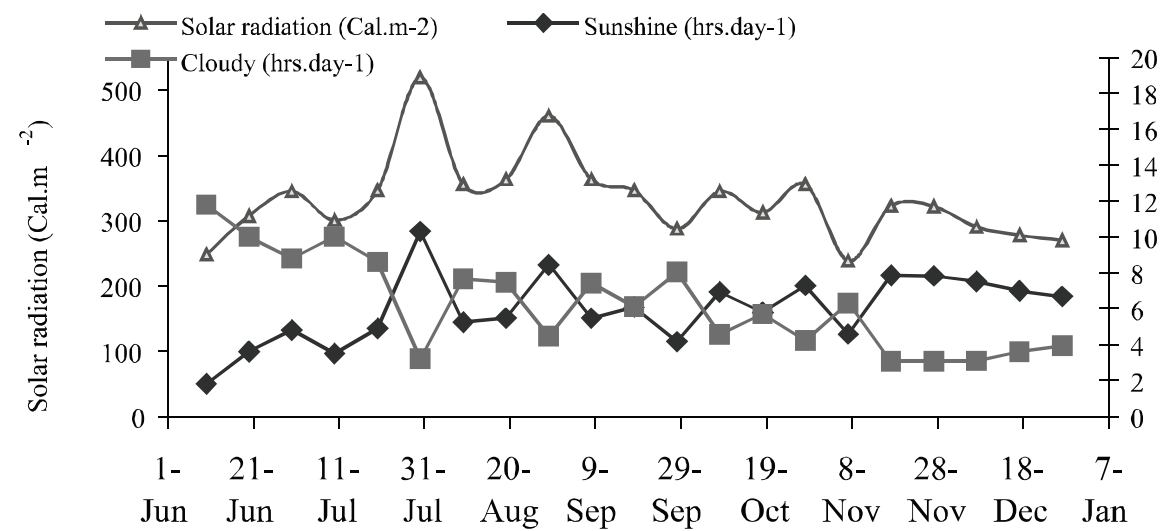

Fig. 5. Sunshine, cloudy hours and solar radiation during whole Aman rice (var. BR11) growing season.

Number of filled grains/panicle also varied significantly due to differences in nitrogen level (Table 1). Increased level of nitrogen significantly increased the number of filled grains/panicle upto $120 \mathrm{~kg} \mathrm{~N} / \mathrm{ha}$. The highest number of filled grains/panicle (109.15) was recorded in $120 \mathrm{~kg} \mathrm{~N} / \mathrm{ha}$ followed by $140 \mathrm{~kg} \mathrm{~N} / \mathrm{ha}$ and the lowest (92.98) was recorded from $80 \mathrm{~kg} \mathrm{~N} / \mathrm{ha}$. Adequate supply of nitrogen contributed to grain development which probably increased number of filled grains/panicle. Further increase in applied nitrogen $(140 \mathrm{~kg} \mathrm{~N} / \mathrm{ha})$ reduced number of filled grains/panicle due to luxariant vegetative growth of the crop. The present results explicitly confirm results obtained by Chander and Pandey (1996).

Filled grains/panicle of the variety increased with four split of nitrogen application. The number of grains/panicle and the nitrogen content of plant leaf before heading is closely related. Sufficient nitrogen is required during the grain filling stage of rice as carbohydrate produced at this stage is mostly translocated to grain. Perhaps, application of $\mathrm{N}$ at 7 days after heading in 4 splits maintained better leaf $\mathrm{N}$ content and subsequently leaf photosynthesis which increased filled grains per panicle.

\section{0-grain weight}

Thousand grain weight of rice varied due to the variation of transplanting date (Table 1). As the planting delayed grain weight decreased, particularly when planted beyond 4 August. Probably due to late planting the grain filling was hampered that decreased individual seed weight. The highest 1000-grain weight (24.83g) was obtained from 4 August transplanting and the lowest 1000-grain weight $(22.51 \mathrm{~g})$ was recorded in 19 August transplanted rice. 
The effect of different nitrogen levels on 1000-grain weight was significant. The bolder grain (23.56g) was found at $120 \mathrm{~kg} \mathrm{~N} / \mathrm{ha}$ and the smaller (22.82g) at $80 \mathrm{~kg} \mathrm{~N} / \mathrm{ha}$ (Table 1). Similar result was also found by Mondel et al. (1987) and concluded that the 1000-grain weight increased with the increasing of nitrogen rate although there is little opportunity to improve this parameter through agronomic management.

The 1000-grain weight, however, was influenced significantly when 4 splits of nitrogen was applied. It might be due to nitrogen top dressing atfter 7 days of heading that favoured absorption of nitrogen efficiently to increase grain number as well as grain size. Top dressing at 7 days after heading of rice gave maximum 1000 -grain weight as 4 splits of $\mathrm{N}$ maintained continuous supply of $\mathrm{N}$ which might favour better seed growth and subsequently bolder seed size (Singh, 1998).

\section{Spikelet sterility}

The percentage of spikelet sterility varied significantly due to the variation of planting dates (Fig. 6). The highest percentage (37.13\%) of spikelet sterility was observed when the crop was transplanted on 19 August. The least number of spikelets sterility (14.91\%) was recorded from the crop planted on 4 August. Both early and late planted crop showed higher percentage of spikelet sterility. The early planted crop experienced lodging at flowering to grain filling stage resulting higher percentage of spikelet sterility. Contrarily, late planted crop being adversely affected by low temperature during flowering stage which result in increase in sterile florets or unfilled spikelet. The results are in agreement with those of Shihua et al. (1991) in other varieties of rice.
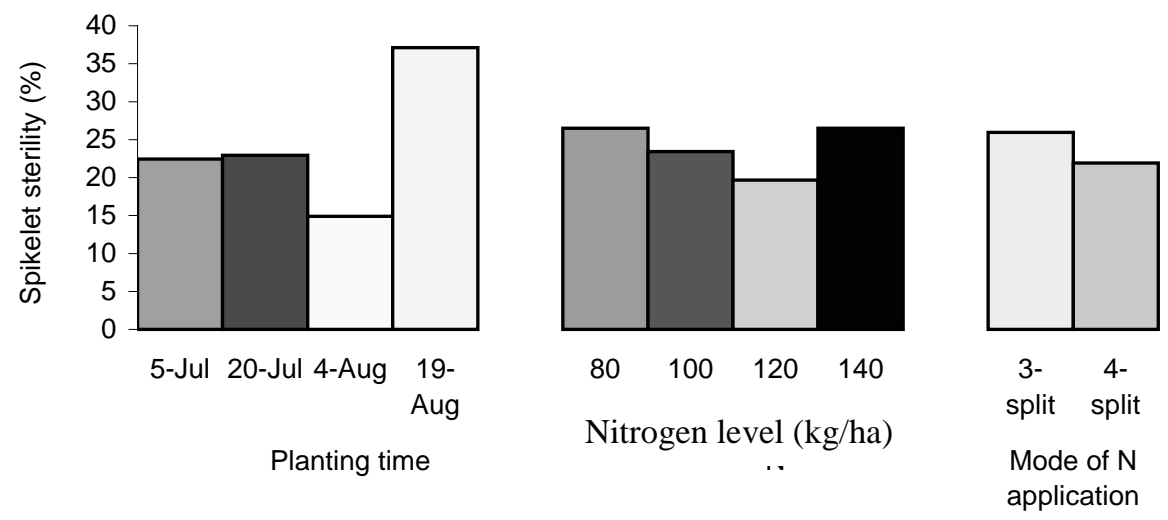

Spikelet sterility was significantly influenced due to the applications of nitrogen (Fig. 6). The highest sterility (26.51\%) was found from the crops which received the highest amount of nitrogen (140 kg N/ha) that was identical to spikelet sterility observed in the crop fertilized with $80 \mathrm{~kg} \mathrm{~N} / \mathrm{ha}$. However, mode 
of $\mathrm{N}$ application reduced spikelet sterility where the lower spikelet sterility (21.91\%) was recorded when 4 splits of $\mathrm{N}$ was done.

\section{Interaction effect}

Interaction effect of planting time, nitrogen level, and mode of nitrogen application on number of filled grains/panicle was significant (Table 2). The lowest number (84.44) of filled grains/panicle was found on 19 August transplanting when fertilized with $80 \mathrm{~kg} \mathrm{~N} / \mathrm{ha}$. The highest number (120.39) of filled grains/panicle was observed on 4 August planting rice fertilized with 120 $\mathrm{kg} \mathrm{N} / \mathrm{ha}$. This might be due to availabitility of better solar radiation associated with optimum temperature during grain growth of rice.

Crop transplanted on 5 July experienced more period of cloudy hours per days (Fig. 5) during reproductive phase and thereby created adverse effect on fertilization and number of filled grains per panicle. Thus the number of filled grains/panicle of earlier planted crop was significantly lower than those under 4 August transplanted rice. Late planted crop also produced lower number of filled grains/panicle. Application of higher level of nitrogen (120 kg N/ha), however, significantly improved the number of filled grains/panicle even under late transplanted condition. Adequate supply of nitrogen contributed to grain development which probably increased the number of filled grains/panicle at increased nitrogen levels under such planting condition. The present results confirmed the results reported by Chander and Pandey (1996).

Interaction effect of applied $\mathrm{N}$ and mode of $\mathrm{N}$ application on filled grains/panicle showed that the highest number of filled grains/panicle (110.08) was found when the crop was treated with 4 splits of $\mathrm{N}$ at the rate of $120 \mathrm{~kg}$ $\mathrm{N} / \mathrm{ha}$. Nitrogen top dressing during the late phase of reproductive growth contributes to sink size development by decreasing the number of degenerated spikelets and increasing the hull size as well as partitioning more assimilates to developing more filled grains per panicle (Mae, 1997).

Table 2. Interaction effect of planting time, nitrogen level and mode of $\mathbf{N}$ application on filled grains per panicle of Aman rice (var. BR11).

\begin{tabular}{|c|c|c|c|c|}
\hline Management & $80 \mathrm{~kg} \mathrm{~N} / \mathrm{ha}$ & $100 \mathrm{~kg} \mathrm{~N} / \mathrm{ha}$ & $120 \mathrm{~kg} \mathrm{~N} / \mathrm{ha}$ & $140 \mathrm{~kg}$ N/ha \\
\hline \multicolumn{5}{|l|}{ Planting time } \\
\hline 5 July & $91.32 \mathrm{cD}$ & $92.43 \mathrm{dC}$ & $97.04 \mathrm{dA}$ & $95.29 \mathrm{~dB}$ \\
\hline 20 July & $95.49 \mathrm{bD}$ & $108.17 \mathrm{bB}$ & 113.63bA & 105.15bC \\
\hline 4 August & 100.68aD & $114.90 \mathrm{aB}$ & 120.39aA & $113.42 \mathrm{aC}$ \\
\hline 19 August & $84.44 \mathrm{dD}$ & $94.34 \mathrm{cC}$ & $105.55 \mathrm{cA}$ & $98.02 \mathrm{cB}$ \\
\hline \multicolumn{5}{|c|}{ Mode of $\mathrm{N}$ application } \\
\hline 3 split & $90.87 \mathrm{bD}$ & $99.47 \mathrm{bC}$ & $108.23 \mathrm{bA}$ & 102.93aB \\
\hline 4 split & $95.09 \mathrm{aC}$ & $103.80 \mathrm{aB}$ & $110.08 \mathrm{aA}$ & $103.00 \mathrm{aB}$ \\
\hline
\end{tabular}

Means in a column, followed by same small letter (s) and in row, by same capital letter do not differ significantly by DMRT at 0.05 levels. 


\section{Grain yield}

Grain yield was significantly influenced by interaction of planting time, nitrogen rates, and mode of $\mathrm{N}$ application (Table 3). The highest grain yield (5.50 t/ha) was found from 4 August transplanted crop fertilized with $120 \mathrm{~kg} \mathrm{~N} / \mathrm{ha}$ at 4 splits of $\mathrm{N}$ application. The highest grain yield obtained from $120 \mathrm{~kg} \mathrm{~N} / \mathrm{ha}$ with 4 split of $\mathrm{N}$ might be due to the cumulative effect of highest number of panicles/hill, filled grains/panicle, and bolder seed size. Top dressing of $\mathrm{N}$ after heading is one way to prevent rapid decline in leaf $\mathrm{N}$ concentration and leaf photosynthesis to reduce sterility percentage (Wada et al., 1986). In the present study, number of filled grains/panicle and seed size increased by an additional top dressing of $\mathrm{N}$ done at 7 days after heading.

The lowest grain yield (1.87 t/ha) was obtained from 19 August transplanting with $80 \mathrm{~kg} \mathrm{~N} / \mathrm{ha}$ when 3 splits were done. In late transplanting, lower amount of nitrogen application decreased the number of panicles/hill and increased unfilled grains per panicle resulting decrease in grain yield of rice. Grain yield decreased at the highest level (140 kg N/ha) of N application. Yield of rice decreased with increased level of nitrogen application in wet season was also reported by Salam et al. (2004). It was assumed that excessive vegetative growth and lodging after flowering increased spikelet sterility which was major reason for lower yield of Aman rice under higher level of $\mathrm{N}$ application. The results are in agreement with the findings of those of Kropft and Splitters (1991) where grain yield was reduced due to increase unfilled grain per panicle.

Table 3. Grain yield of Aman rice (var. BR11) as affected by planting time, nitrogen level, and mode of $\mathrm{N}$ application.

\begin{tabular}{l|c|c|c|c|c|c|c|c}
\hline \multirow{2}{*}{$\begin{array}{l}\text { Planting } \\
\text { time }\end{array}$} & \multicolumn{2}{|c|}{$80 \mathrm{~kg} \mathrm{~N} / \mathrm{ha}$} & \multicolumn{2}{c|}{$100 \mathrm{~kg} / \mathrm{ha}$} & \multicolumn{2}{c|}{$120 \mathrm{~kg}$ N/ha } & \multicolumn{2}{c}{$140 \mathrm{~kg}$ N/ha } \\
\cline { 2 - 9 } & $3 \mathrm{split}$ & 4 split & 3 split & 4 split & 3 split & 4 split & 3 split & 4 split \\
\hline 5July & $3.4 \mathrm{bC}$ & $3.38 \mathrm{bC}$ & $3.82 \mathrm{bB}$ & $3.99 \mathrm{bB}$ & $4.12 \mathrm{bA}$ & $4.32 \mathrm{bA}$ & $4.14 \mathrm{bA}$ & $4.01 \mathrm{bB}$ \\
20July & $3.79 \mathrm{aC}$ & $3.95 \mathrm{aC}$ & $4.10 \mathrm{aC}$ & $4.73 \mathrm{bB}$ & $4.64 \mathrm{aB}$ & $5.12 \mathrm{aA}$ & $4.44 \mathrm{aB}$ & $4.13 \mathrm{aC}$ \\
4August & $3.92 \mathrm{aC}$ & $4.06 \mathrm{aC}$ & $4.64 \mathrm{aB}$ & $5.32 \mathrm{aB}$ & $4.81 \mathrm{aB}$ & $5.50 \mathrm{aA}$ & $4.98 \mathrm{aB}$ & $4.48 \mathrm{aB}$ \\
19August & $1.87 \mathrm{cC}$ & $1.92 \mathrm{cC}$ & $2.46 \mathrm{cB}$ & $2.71 \mathrm{cB}$ & $3.23 \mathrm{cA}$ & $3.17 \mathrm{cA}$ & $3.79 \mathrm{cA}$ & $3.39 \mathrm{cA}$ \\
\hline
\end{tabular}

Means in a column, followed by same small letter (s) and in row, by same capital letter do not differ significantly by DMRT at 0.05 levels.

\section{Soluble protein}

Total soluble protein of freshly harvested rice seed was significantly influenced by planting time, $\mathrm{N}$ level, and mode of $\mathrm{N}$ application (Table 4). Total soluble protein ranged from 5.12 to $9.27 \mathrm{mg} / \mathrm{g}$, which is in agreement with the findings of Sinclair and De Wit (1975) who found 8 to16\% proteins in cereal 
seed. The highest total soluble protein $(9.27 \mathrm{mg} / \mathrm{g})$ was estimated from the seeds of 4 August planted crop fertilized with $120 \mathrm{~kg} \mathrm{~N} / \mathrm{ha}$.

Table 4. Interaction effects of planting time, nitrogen level and mode of $\mathrm{N}$ application on soluble protein (\%) of Aman rice (var. BR11).

\begin{tabular}{l|c|c|c|c|c|c|c|c}
\hline \multirow{2}{*}{\begin{tabular}{c} 
Planting \\
\multicolumn{1}{c}{ Time }
\end{tabular}} & \multicolumn{2}{|c|}{$80 \mathrm{~kg} \mathrm{~N} / \mathrm{ha}$} & \multicolumn{2}{c|}{$100 \mathrm{~kg} \mathrm{~N} / \mathrm{ha}$} & \multicolumn{2}{c|}{$120 \mathrm{~kg} \mathrm{~N} / \mathrm{ha}$} & \multicolumn{2}{c}{$140 \mathrm{~kg}$ N/ha } \\
\cline { 2 - 10 } & $3 \mathrm{split}$ & $4 \mathrm{split}$ & 3 split & $4 \mathrm{split}$ & $3 \mathrm{split}$ & $4 \mathrm{split}$ & $3 \mathrm{split}$ & 4 split \\
\hline 5 July & $5.87 \mathrm{bD}$ & $6.22 \mathrm{bC}$ & $6.32 \mathrm{bC}$ & $6.77 \mathrm{bC}$ & $7.02 \mathrm{aB}$ & $7.41 \mathrm{cB}$ & $7.74 \mathrm{bB}$ & $8.57 \mathrm{aA}$ \\
20 July & $6.71 \mathrm{aC}$ & $7.12 \mathrm{aB}$ & $7.40 \mathrm{aB}$ & $7.85 \mathrm{aB}$ & $7.77 \mathrm{aB}$ & $8.33 \mathrm{bA}$ & $8.82 \mathrm{aA}$ & $7.27 \mathrm{bB}$ \\
4August & $6.04 \mathrm{aD}$ & $6.40 \mathrm{bD}$ & $6.69 \mathrm{bD}$ & $7.24 \mathrm{aC}$ & $6.78 \mathrm{bD}$ & $9.27 \mathrm{aA}$ & $7.80 \mathrm{bC}$ & $8.38 \mathrm{aB}$ \\
19 August & $5.12 \mathrm{bC}$ & $5.64 \mathrm{cC}$ & $5.68 \mathrm{cC}$ & $6.14 \mathrm{bB}$ & $6.35 \mathrm{bB}$ & $6.77 \mathrm{~dB}$ & $6.90 \mathrm{cB}$ & $7.50 \mathrm{bA}$ \\
\hline
\end{tabular}

Means in a column, followed by same small letter (s) and in row, by same capital letter do not differ significantly by DMRT at 0.05 levels.

\section{Conclusion}

Treatment receiving 4 August was the best in recording the number of filled grains (113.05/panicle) and 1000-grain weight of T.Aman rice. Among the nitrogen treatments, $120 \mathrm{~kg} \mathrm{~N} / \mathrm{ha}$ produced the highest number of filled grains/panicle as well as heavier 1000-grain weight of T.Aman rice. On the other hand, 4 split applications produced the highest value of different important parameters of the crop.

\section{References}

Ali, S.M. M., M. M. Haque, A. B. Siddique, A. F. Mollah and M. N. Islam. 2005. Effect of sowing date on the phenology growth and seed yield of tossa jute (Corchorus olitorius L.) in late sown condition. Bangladesh J. Agric. 27 \& 28: 91-97.

Baloch, M. S., I. U. Awan and G. Hassan. 2006. Growth and yield of rice as affected by transplanting dates and seedlings per hill under high temperature of Dera Ismail Khan. Pakistan. J. Zhejiang. Univ. Sci. B. 7: 572-579.

BBS. 2009. Statistical Yearbook of Bangladesh. Bangladesh Bureau of Statistics, Ministry of Planning, Government of the People's Republic of Bangladesh.

Castillo, A. G., J. G. Hampton and P. Coolbear. 1994. Effect of sowing dates and harvest timing on seed vigor in garden pea (Pisum sativum L.). New Zealand J. Crop and Hort Sci. 22: 91-95.

Cataldo, D. A., L. E. Schrader and V. L. Young. 1974. Analysis by digstetion and colorimetric assay of total nitrogen in plant tissues high in nitrogen. Crop Sci. 14: 854-856.

Chander. S. and Pandey. 1996. Effect of herbicide and $\mathrm{N}$ on yield of scented rice under different rice cultures. Indian J. Agron. 41: 209-214.

Copeland, L. O. 1976. Principles of Seed Science and Technology. Burgess Pub. Com. Minneapolis. Minnesota. Pp. 164-165. 
Dey, M. M., M. N. I. Miah, B. A. A. Mustafi and M. Hossain. 1996. Rice Production constraints in Bangladesh: Implications for Further Research Priorities. Rice Research Priorities. Rice Research in Asia: Progress and Properties. Intl. Rice Res. Inst. Pp. 179-199.

FAO. 1998. Food and Agricultural Organization the United Nations. Rice grain of life. P. 44.

Haider, J., T. Marumoto and A. K. Azad. 1991. Estimation of microbial biomass, carbon and nitrogen in Bangladesh soils. Soil Sci. \& Plant Nutr. 37:591-599.

Henan, D. P. and P.E. Bacon. 1987. Effect of nitrogen fertilizer timing on crop growth and nitrogen growth and nitrogen use efficiency by different rice varieties in southern Australia. In: Efficiency of nitrogen fertilizer on rice. Intl. Rice Res. Inst. Los Banos. Philippines: 97-105.

ISTA. 2006. International rules for seed testing. International Seed Testing Association (ISTA), Bassersdorf, Switzerland.

Juliano, B.O. 1972 Phsicochemical properties of starch and protein in relation to grain qulity and nutritional value of rice. In Intl. rice Res. Inst. Rice Breeding. Pp.389-405.

Khush, G. S. 1996. Prospect and approaches to increasing the genetic yield potential of rice. Rice Research in Assia ; Progess and priorities . Intl. Rice Res. Inst. Edited by R. E. Evension, R. W. Herdt and M. Hossain. Pp. 59 -71.

Mae, T. 1997. Physiological nitrogen efficiency in rice. Nitrogen utilization, photosynthesis and yield potential. In: Ando, T., K. Fujita, T. Mae, H. Matsuto, S. Mori and J. Sekiya (eds). Plant nutrition for sustainable food production and environment. Kluwer Academic Publishers, Printed in Japan.

Mannan, A. 2005 Effect of planting date, $\mathrm{N}$ fertilization and water stress on growth, yield and quality of fine rice. (Ph. D Thesis. Dept. of Agronomy BAU.) Mymenshing.

Maske, S. R. Saggar, M. S Maskina and R. S. Rakhi. 1997. Rice cultivation for the million, Japan Scientific Society Press, Tokyo, Japan.

Mikkelsen, D. S, J. R. Jayaweera and D. E. Rolston. 1995. Nitrogen fertilization practices of low land rice culture. $N$ fertilization in the Environment: $171-223$.

Mondal, S. S, A. N Dasmahapatra and B. N Chaterjee. 1987. Effect of high rate of potassium and nitrogen on rice yield components. Env. and Ecol. 5: 300 -303.

Schnier, H. F., Dingkihn., S. K. De Datta, K. Mengel. 1990. Nitrogen fertilization of direct seeded flooded vs. transplanted rice. Nitrogen uptake, photosynthesis, growth and yield. Crop Sci. 30: 1276-1284.

Shihua, C., S. Zougiu and Si Huamin. 1991. Simulation of the effect of temperature on spokelet fertility in rice and consequences for rice production. P. 73-78.

Sinclair, T. R. and C. T. de Wit. 1975. Photosynthate and nitrogen requirements for seed production by various crops. Science 189: 565-567

Sing, H. and S.S. Gill. 1981. Effect of seed size and sowing dates on seed crop of pea. Seed Res. 9: 122-125. 
Singh, A. K and L. Singh. 2007. Role of thermal time in rice phenology. MKK Publication, Calcutta, India.

Singh, R. S. and S. B. Singh. 1998. Response of rice (Oryza sativa) to age of seedlings and level and time of application of nitrogen under irrigated condition. Indian J. of Agronomy 43: 632-635.

Wada, G., S. Shoji and T. Mae. 1986. Relationship between nitrogen absorption and growth and yield of rice plants. Jpn. Agric. Res. Q. 20: 135-144.

Yoshida, S. 1981. The physiology of silicon in rice. Technical Bulletin No. 25. Food Fertilization Technology Center. Taipei, Taiwan. 